\title{
Creating a Constitutional Framework for Spending
}

\author{
Katie Norman
}

Memorial University of Newfoundland

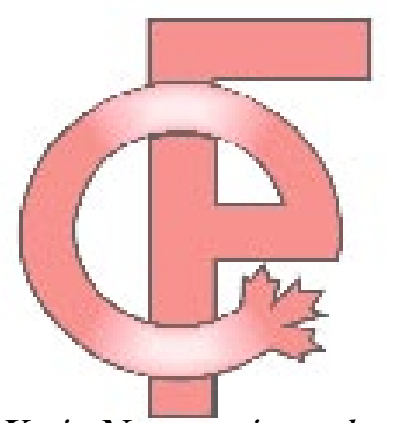

Katie Norman is graduating in May 2006 with a Bachelor of Arts (Honours) in political science and a certificate in public administration from Memorial University of Newfoundland. Her undergraduate dissertation researched the emergence and evolution of the Intergovernmental Affairs Secretariat in Newfoundland and Labrador. Katie, as President of the United Nations Society at Memorial and Vice President of the United Nations Association in Canada - St.John's Branch, is also interested in intergovernmental relations between soverign states. Katie has attended and staffed Model UNs in Canada, the United States and United Kingdom. She plans to continue her studies on the federal spending power and intergovernmental affairs at Queen's University this fall in the Master of Public Administration program. While in Kingston, Katie plans to continue SSHRC-funded research on the federal spending power. 
"The power of Parliament to make payments to people or institutions or governments for purposes on which it does not necessarily have the power to legislate" $^{\mathrm{i}}$ is known as spending power. This power is exercised through conditional grants to provinces, equalization payments or block grants, and payments made directly to institutions or individuals." There are various disputed reasons for the exercise of spending power by the Federal Government. Such reasons include the federal government gaining more control over provincial resources, and ensuring that Canadian standards in social programs are maintained. Since the rise of its popularity in the 1940 s, spending power has been a contested practice. This has lead to debate on whether or not it should be constituionalized. In the 1990s during a period of economic downturn, budgetary concerns, privatization and deregulation, spending power became less frequently used; however the federal goternment still has a great deal of financial controtover many different areas that fall within provincial jurisdiction. Considering its importance and impact on Canadian politics, spending power should be constitutionalized, on account that it would create greater equality in the practice of the power between provinces, allow greater accountability towards both levels of government and attribute greater legitimacy toward this power.

\section{Constitutionalization of Spending Power: A Checklist}

There are many grounds as to why spending power should be constituionalized. To begin, the spending power is viewed by many as a unilateral federal action. The power is seen by provinces, moreover, as an attempt to centralize the control of several programs within the federal government. Provinces contest this control since it, "distorts their own priorities in favor of program fields in which the federal government stands ready to pay half of program costs." "iii (I would prefer the earlier statement to continue to read "Provinces contest this control because they say it," instead of "since it" as this is debatable.) There is also a level of uncertainty on the amount of money that each side will have to pay in cost sharing programs, which leads to future conflicts over costs. Furthermore, while it is unilateral not all provinces have received the same benefits, especially in the field of post-secondary education, from spending power. ${ }^{\text {iv }}$ Consequently such action needs to be reconstructed to create a Canadian union that collaborates between both federal and provincial governments and which also instills some measure of provincial control." If the actual terms of spending power were constituionalized and accepted by all provinces and the federal government, than hopefully legitimacy would be awarded to spending power, thus minimizing the view that it is a unilateral federal action. Ultimately, federal government control over provincial domain needs to be legitimized."

Secondly, Parliament should be able to provide funding to any provincial program that it chooses unless it demands conditions on the allotted monies that are not acceptable to the provinces and 
conflict with their plans. Spending power, though contested, should not be banned. This idea is motivated by the fact that provinces usually contest the conditions placed on cost shared programs, not spending power itself. ${ }^{\text {vi }}$ Outlining that Parliament can use spending power, as long as they do not impose conditions on the monies, would give further legitimacy to spending power. Hence the Federal government's role in establishing and maintaining social policy norms and programs, for the purpose of bringing fair distribution and equality of initiatives to all Canadians ${ }^{\text {viii }}$, should be entrenched in the Canadian constitution.

Thirdly, an outline of national and per capita reimbursement for provinces opting-out from conditional grants needs to be firmly established. ${ }^{\text {" }}$ This enforces the need to create a favorable opt out formula. Provinces have sought a solidification of the "opt-out" policy,allowing provinces to create their own programs that meet national objectives and receive financial compensation for this. ${ }^{x}$ If a standardized opt-outing out formula is not established, then provinces may not receive equal monetary equivalents for opting out of the same program.

Fourthly, increased input in planning and some level of funding autonomy for provinces involved in cost sharing programs, ${ }^{\text {xi }}$ need to be instituted. Provinces have long contested the use of spending power, on account that the premise of federal control in provincial jurisdiction tends to evoke the idea of emergency federalism in which the federal government took control of matters within provincial jurisdiction, a form that was in place during both World Wars. Provinces are unlikely to support any constitutional outline of spending power if it greatly reduces their autonomy and places them in a subservient position to Ottawa. Spending power should be seen as an exercise of cooperative federalism, not emergency federalism.

Due to the constitutionalization of the federal spending power the inefficiency and duplication of past programs could be minimized. It has been suggested that claims of over-government in the social arena could be clarified and resolved through annual reviews of spending power at First Ministers Conferences. $^{\text {xii }}$ Moreover, the establishment of spending power to the constitution would perhaps allow the further clarification of intergovernmental relations, for it lacks legitimacy, transparency and accountability.

Spending power needs to be constituionalized to outline consent alternatives for cost-sharing programs and block grants, to set out the rules of opting out of spending power initiatives, outline the scope of programs within which spending power could be used and set guidelines for financial agreements. xii $^{\text {in }}$ Such agenda needs to be considered for the demands have been the cause of many attempted, and some successful, amendments and agreements. Examples of such amendments and agreements include the Meech lake Accord, Shaping Canada's Future Together: Proposals, the Charlottetown Accord, and A 
Framework to Improve the Social Union for Canadians.

\section{Current Constitutional State of Spending Power}

Despite the federal government's use of spending power in the past sixty years, and the level of protest generated by the provinces against it, spending power is not explicitly outlined or even mentioned in the Constitution Act 1867. 7. Due to this situation it has remained the role of the judiciary to determine if spending power is constitutional. Therefore the courts have determined that the Constitution Act 1867 gives "the Parliament of Canada the power to spend from the Consolidated Revenue Fund on any object, provided the legislation authorizing the expenditures does not amount to a regulatory scheme was falling within provincial powers." ${ }^{\text {"iv }}$ This ability is backed by the following sections of the Constitution:

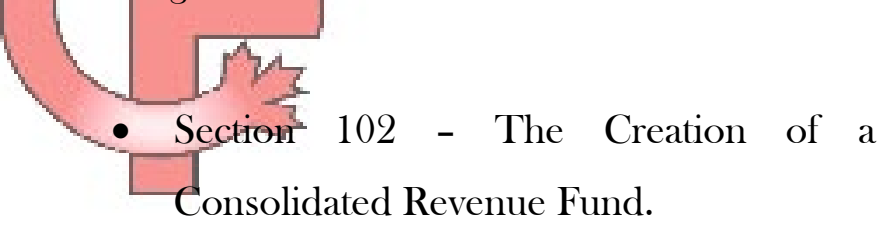

- Section 91(1A)- Parliament's allowance to legislate on matters of public debt and property.

- Section 91-3 - Parliament of Canada's ability to raise money by any mode of taxation.

- Section 106 - Parliament's ability to appropriate funds. ${ }^{x}$
To begin, while the Consolidated Revenue Fund has been omitted, the capacity of the Federal government to use both direct and indirect taxation has sustained the ability of the federal government to financially exercise spending power. Secondly, Section 91(1A) allows broad definitions of "public debt and property" to be drawn. ${ }^{\text {xi }}$ This means that one may claim that any areas upon which spending power is exercised exist within the realm of public debt and property. This notion was further solidified in "Shaping Canada's Future Together, Proposals," a 1991 Constitutional reform package, which stated that judicial interpretation had confirmed the constitutional basis of spending power due to federal powers over public debt and property. ${ }^{\text {xii }}$ As a final point through Section 106 the government is able to appropriate funds that they can set aside for specific uses. The combination of each of these sections provides a minimal backing for spending power. Nevertheless, since it does not outline any limits or specifics it illustrates how there is definite room for improvement.

Judicial interpretation has allowed spending power to exist with relative legitimacy, however it has not established a framework from which full legitimacy can be obtained. Spending power was not exercised until after 1945 when a greater concern for social welfare arose and the idea of the "optimal federal state" formed "based on two assumptions. First, it was implicitly assumed that the role of the states was to specify public policies and programs, which would 
augment consumer welfare. Secondly, insofar as output was concerned, it assumed that governments should only supply collective goods." xiii (This is where the quote ends, it begins with "based on two assumptions" These assumptions lead the federal government to pursue spending power as a solution to solving social problems within the state. As it is not constitutionalized, it makes it difficult for either level of government to define infringements or limits on their powers.

Spending power, practices, views and various forms have changed in relation to the government of today. As the demands change so do the programs and thus the funding of the programs. In the pursuit of the welfare state, for example, the role of the federal government and spending power has changed over time. This has been marked by the transition from an authoritative and centrist view of power since in the 1950 s to 1960 s, to the role of conditional grant provider between 1967 and 1977, and finally to a government with considerable control over expenditures..$^{\text {ix }}$ All the same this evolution has had one constant belief that has almost become a convention in Canadian politics, it being that excess revenues would be used to support and maintain social and other programs under provincial jurisdiction. $^{\mathrm{xx}}$ Due to this evolving role of spending power and its various forms, it has been difficult to create a constitutional framework that is accepted by both levels of government.
If accepted that spending power is necessary to maintain the welfare state, than the next step is to consider a framework for spending power. Creating a set outline for opting out is one of the benefits of codifying spending power. Opting out refers to the ability of provinces to refrain from the use of spending power within their province. ${ }^{x i}$ Quebec, in case in point, and the other provinces have pursued through a variety of initiatives this goal with the Federal government in a number of documents. ${ }^{\text {xii }}$ Provinces want definitive opt-out compensation if they establish programs similar to those initiated by the federal government. Opting out, if accepted as a practice, needs to be consistent across provinces and programs. Thus, codifying opting out would then remove the ad hoc way that is being dealt with currently.

Consequently, through section 40 of the Constitution Act, 1982, the compensation for opting out in some types of programs became constitutionally enforceable. The section gave provinces the ability to withdraw from any constitutional amendment that affected its legislative powers (if the item concerned cultural or education matters) $)^{\text {xiii }}$ and requiring the federal government to give "reasonable compensation to any province to which the amendment does not apply." ${ }^{\text {xiv }}$ But if spending power was further codified, the areas within which compensation can be given could be expanded to include heath care. However, ensuring compensation helps to limit the belief that spending power is a unilateral federal action and boosts provincial autonomy. Quebec debated, for 
illustration, if it was to accept the document it would have to be granted further autonomy and a specific boundary on spending power entrenched in the Constitution 1982, They specified "education, labour market training and health," as areas that were unacceptable for spending power to be utilized within. ${ }^{x v}$ This did not happen, nevertheless, their comments only bolster the case that the entire act if spending power, and not just opting out need to be entrenched in the constitution.

After the comments made by Quebec, the federal government went on to support the Calgary Declaration of September 14, 1997 and its initiatives regarding spending power. ${ }^{x x i}$ This seventh principal would go on to draft a new relationship between federal and provincial levels of government. Moreoyer, create a mutual goal of providing effective social programs, which need a joint partnership between all provinces, territories and the federal government to ensure that the needs of its citizens were fulfitted. ${ }^{\text {xxii }}$ Nonetheless, all provinces, excluding Quebec, have ratified the Calgary Declaration thus solidifying the need of both levels of government to work cooperatively together with regards to spending power and social program funding. xxiii

In the Calgary Declaration there was great emphasis placed on mutual respect between both levels of government. This was a direct translation of Parliament's generalized change in the type of spending power it exercised, going from cost sharing to unconditional block transfers that occurred in the mid-1990s. ${ }^{\text {xix }}$ A few conditional grants still occur, some of the most conflictual dealing with post-secondary scholarships and research $^{\mathrm{xxx}}$ such as the Millennium Scholarship. If spending power were constitutionalized, provincial governments would have some concrete outlines from which they could make complaints about such conditional grants.

The Calgary Declaration was expanded into the "Framework for Improving the Social Union of Canadians,” and signed by the federal government and all provinces( except Quebec)on February 4, 1999. ${ }^{\text {xxi }}$ The document recognized the essential use of spending power in the creation and implementation of many social programs. Spending power helps support social programs in Canada and allows equality of opportunity, access and mobility to all Canadians while also helping to pursue domestic objectives. ${ }^{\text {xxii }}$ Furthermore, establish initiatives, regarding opt-out compensation and annual reviews of spending power, which had been previously attempted in both the Meech Lake and Charlottetown Accords. In addition progress has been made by creating mandatory threemonth discussions prior to the implementation of programs in which both sides may propose amendments and alternatives. ${ }^{\text {xxiii }}$ Perhaps the reason for this being because it was not combined with other initiatives, such as linguistic rights and Senate or House of Commons reform, as many previous accords and documents had been. Despite the favorable gains made, even so this document did little more than sustain the status quo. ${ }^{\text {xxiv }}$ This document 
did not limit the federal government's ability to spend in areas of provincial jurisdiction.

\section{A Point and Counterpoint Scenario on Spending Power - Duplessis and Trudeau}

The debate surrounding spending power can be seen as having both supporters and challengers. Due to the notion of centralization and decentralization. In opposition of spending power are people who think it contradicts representative democracy and limits provincial autonomy in favor of a centralized dominant federal government. ${ }^{\mathrm{xxv}}$ Former Quebec Premier Maurice Duplessis, in his 1956 statements articulated these views and sought to rival the Federal power with his provincial power. ${ }^{\text {xxxi }}$ In the opinion of Duplessis, the role of "goodwill provider" adopted by the Trudeau government in the creation of the welfare state was "undermining of representative democracy." Quebec in its pursuit of greater autonomy, for since the Duplessis administration, all Quebec premiers have contested Federal actions within their boarders. Moreover, such demonstrations have been seen in their failure to ratify such documents as the Calgary Declaration, which is why in order to codify spending power reconciling the interests of both orders of government is necessary so that a formula may be established and agreed upon.

This observation is contrasted with the view that spending power is necessary to maintain a welfare state and should be accepted by provinces for this reason. Former Prime Minister Pierre Elliot Trudeau's comments on spending power embody these views. Trudeau promoted the idea that Canadians should accept Federal acts of spending power when a province's economical situation does not provide for optimum services. ${ }^{\text {xxvii }}$ If the federal government can afford to pay for, or better a program then it is in the best interest of all Canadians to accept this. Yet he also maintained that there needs to be a division of powers so that citizens were "able to determine easily which government is responsible for what: otherwise the domestic control of behaviour becomes impossible" ${ }^{\text {xxix }}$ and that spending power must not cloud this division. If spending power is going to be constituionalized then a compromise between both views is necessary.

Spending Power Programs: Case Studies on What Has Been Implemented In The Past

In figuring out what a constitutional outline of spending power should look like it is beneficial to look at some past programs and their weaknesses and strengths. These programs not only reveal what has been accepted and what has been rejected, thus giving some indication on the boundaries that can be drawn in codifying the power, but they also show the important areas that need to be addressed. One of the first necessities is to clarify the administrative and accounting aspects of opting-out. Demonstrations seen in the 1965 Established Programs (Interim Arrangements) Act, set up in order to help control 
the accounting aspects of cost sharing programs. ${ }^{\mathrm{x}}$ However only Quebec chose to use this opt out opportunity. ${ }^{\text {xi }}$ Many critics have cited this as a fortunate occurrence "since the technical problem of establishing fiscal equivalence through appropriate tax abatement increases rapidly with the number of provinces opting out." ${ }^{\text {kli }}$ Despite providing autonomy to the provinces, opting out is administratively difficult. A program needs to be established so that opting-out and its administration are less complicated. Opt out possibilities were also offered in further documents ${ }^{\text {xiii }}$ in 1966 and 1973. ${ }^{\text {xiv }}$ These documents also revealed that many provinces viewed opting-out as a benefit only for the federal government. ${ }^{\text {xv }}$ Opting out should be seen as a benefit to the provinces so that they can exercise further autonomy and also as something that is not a logistical nightmare for the federal government to administer.

The second inevitability is to please the provinces on some level. This is not to say that spending power should become a power that's only concern is province building. Trudeau's First Minister's Conference in 1969 attempted to create a favorable version of spending power for the provinces through a constitutional framework. ${ }^{\text {xli }}$ If a proper outline were devised it would relieve the necessity to rely on judicial interpretation, and would clarify the roles, rights and limits of both levels of government. This appeasement must not come at the expense of program standards however. xlii $^{\text {tii }}$
Moreover, a stipulation must be installed in the constitutional framework instituting the principals of cooperation between the federal and provincial governments. Established Programs Financing (EPF) was introduced in 1977 as a way to "maintain a viable balance between [Canada's] objectives of promoting national standards in specific program areas (through conditional grants) and meaningful fiscal autonomy among provincial governments (through

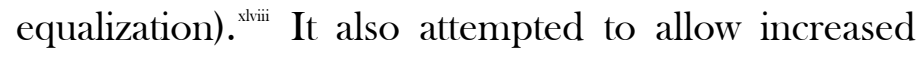
planning input and funding autonomy for provinces when dealing with cost-sharing programs. ${ }^{\text {xlix }}$ Programs were linked together and provinces were given block transfers for each group. Institutionalizing blocks of programs and then issuing block transfers, as was done in EPF, may be the most viable option that promotes cooperative federalism.

A fourth consideration when codifying power can be seen as a result of the 1978-79 constitutional discussions. This is the consideration of a provincial consent mechanism. It was decided then that "the exercise of the federal spending power would [be] made subject to a provincial consent mechanism with unconditional compensation for non-participating provinces." The devotion in this best efforts draft to create a consent mechanism could be seen as a gain for the provinces to move towards effective spending power programs and opt out policies.

The Meech Lake Accord and its subsequent rejection reveal a fifth matter when codifying spending power. The Meech Lake Accord, pushed by Quebec, 
sought to expand on the Constitution Act, 1982 and allow compensation to be given for all areas within which cost shared programs were exercised." Compensation was however conditional on the creation of a comparable initiative to the national objectives. ${ }^{\text {lii }}$ Conversely, this was not meant to extend the powers of the provinces or Parliament. lii $^{\text {li }}$ Unfortunately this amendment did not pass as Meech Lake ultimately failed, although it was mainly due to uncertainty surrounding the "distinct society clause" and not necessarily the amendments to spending power. When codifying the power extending the areas within which opting out can occur would be advisable.

Furthermore, the sixth deliberation to consider, is made clear in the 1991 federal constitutional reform package - "Shaping Canada's Future Fogether, Proposals." A key statement in the package admitted to the possibility of provinces carrying out social programs autonomously from the Federal government. ${ }^{\text {liv }}$ While this statement came from a time of mass government privatization, and where reform budget was necessary thus resulting in limited government spending, it did recognize that spending power is not necessary in the setup and maintenance of all social programs. This fact should be clarified in the framework.

A seventh requirement can be found in section 25 of the Charlottetown Accord: ${ }^{\text {lv }}$ the necessity to place some limits on spending power. The Accord stated that spending power could only be then exercised if it contributed to national objectives, reduced duplication, was respectful for provincial priorities, and offered equality and recognition of differences in need and circumstances to the provinces. $^{\text {li }}$ It also stated that First Ministers conferences, for review of spending power practices, would also be constituionalized. ${ }^{\text {lvi }}$ Ultimately the Charlottetown Accord failed in a national referendum and these amendments did not occur. Nevertheless, intergovernmental reviews of spending power and limits on the power need to be established.

Contemplation, however is the rigidity of an outline of spending power. After the creation of the Canada Health and Social Transfer, which replaced the Established Programs Fund and Canada Assistance Plan, kiii a 1995 "Report to Premiers" by the Ministerial Council on Social Policy Reform and Renewal, issued a request for federal limitations on the use of spending power. Spending power should not be a mechanism for unilateral federal say in the creation or objectives of social programs. ${ }^{\text {lix }}$ This report however, did not suggest a rigid outline for spending power but suggested "improved flexibility and accountability." ${ }^{\prime \prime}$ Accountability and flexibility need to be considered but should not be so limited to the extent that they simply allow the federal government to impose programs on the provincial governments.

Finally, the statement made by the Federal government during the 1996 Speech from the Throne showed a commitment by Parliament to only create new programs with the consent of a majority of the provinces and any opting out province that qualifies 
will receive adequate financial compensation. ${ }^{\mathrm{ki}}$ This commitment was expanded upon in the Report to Premiers in 1997, entitled "New Approaches to Canada's Social Union, "xii where it stated that financial agreements must not be subject to unilateral change, thus attempting to create a level of security over the Federal portions of cost shared programs, which had proved to be problematic in the past due to federal withdrawal from financial support. ${ }^{\text {liii }}$ The federal government must uphold its financial commitments to shared cost programs and the division of costs needs to be established prior to the construction of any spending power program.

\section{Conclusion}

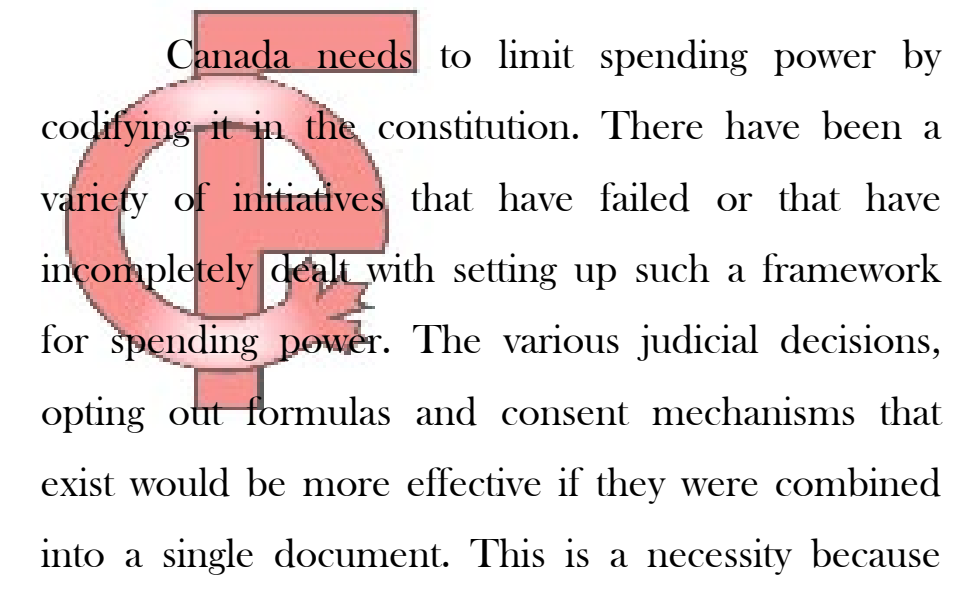

Canada is a federation in which many provinces spend more than they can generate in tax revenues. ${ }^{\text {kiv }}$ Fiscal imbalance has lead not only to the use of spending power in areas of education, health care and other social services since the end of the Second World War, but a shift in the constitutional powers of both Canada's codified and uncodifed constitution. ${ }^{\text {kv }}$ While various documents have been signed and ratified recognizing the need of spending power to maintain equality of programs and resources, this has done little to change the unilateral nature of this power in Canada. The transfer from conditional grants and matching grants to block grants and tax points has only changed the mechanism with which Federal economic domination is carried out. The Judiciary has stated that the Federal government has the right to exercise spending power but not to implement legislation; they may only offer financial support. Spending power has been maintained for the past fifty years and Ottawa's power over the provinces has ultimately been maintained. Furthermore, while the names and particulars of some of the programs have changed, the control Ottawa has over the provinces is still very much in tact today. There is a need to constitutionalize spending power to redistribute the division of powers between Ottawa and the periphery.

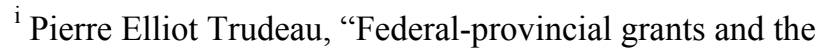
spending power of Parliament," in Economics: Contemporary Issues in Canada, ed. D.A.L. Auld (Toronto: Holt, Rinehart and Winston of Canada, 1972), 3.

ii Christopher Dunn, "The Federal Spending Power" in The Handbook of Canadian Public Administration. ed. Christopher Dunn, (Don Mills, Ont.: Oxford University Press, 2002), 225.

iii Malcolm C. Brown, Established Program Financing: Evolution or Regression in Canadian fiscal federalism? (Canberra, Australia: Center for Research on Federal Financial Relations, Australian National University: Distributed by ANUTECH, 1984), 21-22.

iv Ibid.

v Ronald L. Watts, "The Spending Power in federal Systems: A Comparative Study." (Kingston, Ont.: Institute of Intergovernmental Relations, Queen's University, 1999), 4. ${ }^{\text {vi }}$ Ibid.

vii Canada, Shaping Canada's Future Together. Proposals. (Ottawa : Minister of Supply and Services Canada, 1991), 3940.

viii Ibid.
} 
ix Trudeau, "Federal-provincial grants and the spending power of Parliament,"7.

${ }^{\mathrm{x}}$ Watts, 4.

${ }^{\mathrm{xi}}$ Brown, 1.

${ }^{x i i}$ Canada, Shaping Canada's Future Together. Proposals, 40-41.

xiii New Approaches to Canada's Social Union: an options paper [essay on-line]; available from

www.scics.gc.ca/pdf/85006109 e.pdf; Internet: accessed 11

March, 2004.

xiv Watts, 1 .

${ }^{\mathrm{xv}}$ This section was a part of the original document accepted by Parliament but has since been omitted.

${ }^{\mathrm{xvi}}$ A similar stretch has been created by many decisions made by the Judicial Committee of the Privy Council on the intent of the Peace Order and Good Government Clause.

xvii Canada, Shaping Canada's Future Together. Proposals, 39-

40.

xviii Brown, 2.

xix Ibid, 15.

${ }^{\mathrm{xx}}$ Robert Jackson and Doreen Jackson, Canadian Government in Transition, (Scarborough, Ont.: Prentice hall, 1999), 85.

${ }^{\mathrm{xxi}}$ Watts, 4.

xxii Some of these initiatives include the Meech Lake and the Charlottetown Accords.

${ }^{x}$ Canadian federalism and the Spending Power of the

Canadian Parliament [essay on-line]; available from

http://www2.marianopolis.edu/quebechistory/federal/spen

ding.htm. Internet: accessed 9 March 2004.

${ }^{x x i v}$ Peter W. Hogg, Constitutional Law of Canada, (Toronto:

Carswell Thomsen Professional Publishing, 1998), 1110.

${ }^{\mathrm{xx}}$ Watts, 3.

xxvi The Calgary Declaration [essay on-line]; available from http://www.ontla.on.ca/library/repository/mon/1000/1027 3337.htm; Internet: accessed 12 October 2004.

xxvii Calgary Declaration: Provincial and Territorial Resolutions [essay on-line]; available from

http://www.uni.ca/cd_res.html; Internet: accessed 9 March

2004.

xxviii Ibid.

${ }^{\text {xxix }}$ Watts, 5.

${ }^{\mathrm{xxx}}$ Ibid.

xxxi Ibid.

xxxii A Framework to Improve the Social Union for Canadians [essay on-line]; available from

www.scics.gc.ca/cinfo99/80003701 e.html; Internet:

accessed 12 March, 2004.

xxxiii Ibid.

xxxiv This was a statement made by Dr. Christopher Dunn of

Memorial University on March 22, 2004, during his lecture for Political Science 3741.

${ }^{\text {xxxv }}$ Garth Stevenson, Unfulfilled Union, (Toronto: Macmillan Company, 1979), 157.
${ }^{\text {xxxvi }}$ Pierre Elliot Trudeau, "I agree with... Some of Mr.

Duplessis' Attitudes" in Issues in Canadian History: Quebec in the Duplessis Era, 1935-1959: Dictatorship or Democracy? ed. Cameron Nish (Toronto: The Copp Clark Publishing Company, 1970), 148.

xxxvii Ibid, 147.

xxxviii Ibid. 147

${ }^{\text {xxxix }}$ Ibid, 146.

${ }^{\mathrm{xl}}$ Ibid.

xli Brown, 20.

xlii Ibid.

xliii Both of these documents referred to health insurance

programs.

xliv Brown, 20.

${ }^{\mathrm{xlv}}$ Ibid, 20-21.

xlvi Trudeau, "Federal-provincial grants and the spending power of Parliament,"7.

xlvii Ibid, 7.

xlviii Brown, 1.

xlix Ibid.

${ }^{1}$ Watts, 2.

${ }^{\text {li }} 1987$ Constitutional Accord [essay on-line]; available from www.solon.org/Constitutions/Canada/English/Proposals/ MeechLake.html. Internet: accessed 9 March 2004.

lii Ibid.

liii Watts, 3 .

${ }^{\text {liv }}$ Canada, Our Future Together - Fact Sheet for Rebalancing Roles and Responsibilities, [Ottawa : Minister of Supply and Services Canada, 1992) 1-2.

${ }^{\text {lv }}$ Watts, 3

${ }^{\text {lvi }}$ Charlottetown Accord [essay on-line]; available from http://www.uni.ca/charlottetown.html; Internet: accessed 9 March 2004.

lvii Ibid.

lviii Watts, 4

${ }^{\text {lix }}$ Canada, Ministerial Council on Social Policy Reform and Renewal Report to Premiers, (Ottawa: The Council, 1995), 18. ${ }^{\mathrm{Ix}}$ Ibid.

lxi Ibid, 9.

${ }^{\text {lxii New Approaches to Canada's Social Union: an options paper }}$ [essay on-line]; available from

www.scics.gc.ca/pdf/85006109 e.pdf; Internet: accessed 11 March, 2004.

lxiii Ibid. 12

${ }^{\text {lxiv }}$ Roger Gibbins, "Taking Stock: Canadian Federalism and Its Constitutional Framework," in How Ottawa Spends: 1999-2000, ed. Leslie A. Pal. (Toronto: Oxford University Press, 1999) 202. ${ }^{\mathrm{lxv}}$ Ibid. 


\section{Works Cited}

1987 Constitutional Accord [essay on-line]. Available from www.solon.org/Constitutions/Canada/English/Proposals/MeechLake.html. Internet: accessed 9 March 2004.

A Framework to Improve the Social Union for Canadians [essay on-line]. Available from www.scics.gc.ca/cinfo99/80003701_e.html. Internet: accessed 12 March 2004.

Brown, Malcolm C. Established Program Financing: Evolution or Regression in Canadian fiscal federalism? Canberra, Australia : Centre for Research on Federal Financial Relations, Australian National University : Distributed by ANUTECH, 1984.

Calgary Declaration: Provincial and Territorial Resolutions [essay on-line]. Available from http://www.uni.ca/cd res.html. Internet: accessed 9 March 2004.

Canada, Ministerial Council on Social Policy Reform and Renewal Report to Premiers. ] Ottawa: The Council, 1995.

Canada, Our Future Together - Fact Sheet for Rebalancing Roles and Responsibilities. Ottawa : Minister of Supply and Services Canada, 1992.

Canada, Shaping Canada's Future Together. Proposals. Ottawa : Minister of Supply and Services Canada, 1991.

Canadian federalism and the Spending Power of the Canadian Parliament [essay on-line]. Available from http://www2.marianopolis.edu/quebechistory/federal/spending.htm. Internet: accessed 9 March 2004.

Charlottetown Accord [essay on-line]. Available from http://www.ani.ca/charlottetown.html. Internet: accessed 9 March 2004.

Dunn, Christopher. "The Federal Spending Power." in The Handbook of Canadian Public Administration. ed. Christopher Dunn. Don Mills, Ont.: Oxford University Press, 2002.

Gibbins, Roger. "Taking Stock: Canadian Federalism and Its Constitutional Framework." In How Ottawa Spends: 1999-2000, ed. Leslie A. Pal. Toronto: Oxford University Press, 1999.

Hogg, Peter W. Constitutional Law of Canada. Toronto: Carswell Thomson Professional Publishing, 1998.

Jackson, Robert, and Doreen Jackson. Canadian Government in Transition. Scarborough, Ont.: Prentice hall, 1999.

New Approaches to Canada's Social Union: an options paper [essay on-line]. Available from www.scics.gc.ca/pdf/85006109_e.pdf. Internet: accessed 11 October, 2003.

Stevenson, Garth. Unfulfilled Union. Toronto: Macmillan Company, 1979. 
The Calgary Declaration [essay on-line]. available from http://www.ontla.on.ca/library/repository/mon/1000/10273337.htm. Internet: accessed 12 October 2003.

Trudeau, Pierre Elliot. "Federal-provincial grants and the spending power of Parliament." In Economics: Contemporary Issues in Canada, ed. D.A.L. Auld, 310. Toronto : Holt, Rinehart and Winston of Canada, 1972.

Trudeau, Pierre Elliot. "I agree with...Some of Mr. Duplessis' Attitudes." In Issues in Canadian History: Quebec in the Duplessis Era, 1935-1959: Dictatorship or Democracy? ed. Cameron Nish, 146-148. Toronto: The Copp Clark Publishing Company, 1970.

Watts, Ronald. L. The Spending Power in Federal Systems: A Comparative Study. Kingston, Ont.: Institute of Intergovernmental Relations, Queen's University, 1999.

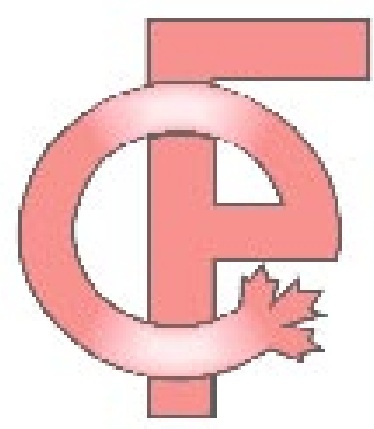

